\title{
A comparison between longitudinal shedding patterns of Salmonella Typhimurium and Salmonella Dublin on dairy farms.
}

M. Kirchner, I. McLaren, F. A. Clifton-Hadley, E. Liebana ${ }^{\dagger}$, A. D. Wales, R. H. Davies*

Department of Bacteriology, Animal Health and Veterinary Laboratories Agency, Woodham Lane, New Haw, Addlestone, Surrey, KT15 3NB, UK.

${ }^{\dagger}$ Current address: European Food Safety Authority (EFSA), Scientific Unit on Biological Hazards, Largo N. Palli 5/A, I-43121 Parma, Italy.

*Author for correspondence

Miranda Kirchner Department of Bacteriology, Animal Health and Veterinary Laboratories Agency, Woodham Lane, New Haw, Addlestone, Surrey, KT15 3NB, UK.

Email: $\quad$ miranda.kirchner@ahvla.gsi.gov.uk

Tel: $\quad+441932359460$

Fax: $\quad+441932357595$

Copyright BMJ Journals.

DOI: $10.1136 /$ vr.100865

Published online at: http://veterinaryrecord.bmj.com/content/171/8/194 


\section{Abstract}

Salmonella in cattle herds may behave as epidemic or endemic infections. An intensive longitudinal sampling study across all management groups and ages on six dairy farms in the UK was used to examine patterns of Salmonella shedding, following the prior identification of either Salmonella Dublin (three farms) or Salmonella Typhimurium (three farms) on the premises in the context of clinical salmonellosis. Individual faeces, pooled faeces and environmental samples (total 5711 samples), taken approximately every six weeks for 15 to 24 weeks, were cultured for Salmonella. S. Dublin was detected at low frequency (on any visit 0.5 to 18.3 per cent of samples positive) and most consistently in calves. By contrast, $S$. Typhimurium was isolated at higher frequency (on any visit 6.8 to 75 percent of samples positive), and in higher numbers, up to $10^{7} \mathrm{cfu} \mathrm{g}^{-1}$ faeces. Significantly more samples from calves were positive for $S$. Typhimurium than were positive for $S$. Dublin $(50.6 \%$ versus $3.1 \% ; \mathrm{p}<0.001)$, which was also true for milking cows $(46.3 \%$ versus $4.4 \% ; \mathrm{p}<0.001)$. The differences could help to explain the different patterns of bovine infection classically associated with these two serovars in the UK. No consistent effect upon shedding was seen among the $S$. Typhimurium-infected herds following vaccination.

Keywords: Cattle, Salmonella, epidemiology, zoonoses

\section{INTRODUCTION}

Clinical Salmonella enterica subspecies enterica infections in cattle in the UK have for decades been associated principally with the two serovars Salmonella Dublin (SD) and Salmonella Typhimurium (ST) (Jones and others 2004, Wray and Davies 2004, Davison and others 2005). In passive surveillance of cattle in Great Britain, Salmonella incidents have fluctuated between 620 and 1196 annually in the last decade. SD and ST accounted for 66\% and 10\%, respectively, of 887 incidents in 2010 (AHVLA 2011). Epidemic and endemic patterns of herd infection have been described for cattle Salmonella infections; the former involving rapid spread, commonly with eventual disappearance, and the latter showing a persistent, fluctuating incidence (Nielsen and others 2004, Sternberg and others 2008, Pradhan and others 2009). Certain serovars or strains have historically been associated with one or other of these patterns, and in the UK, ST and SD have been regarded respectively as the classic 'epidemic' and 'endemic' serovars (Wray and others 1989, Wray and Davies 2004).

SD is considered to be host-adapted, showing a preference for cattle and occurring less frequently in other hosts. In British cattle there is a steady, fluctuating incidence (Wray and Davies 2004, Carrique-Mas and others 2010) . A distinctive feature is the apparently common phenomenon of long-term carriage of SD by infected adult cattle with continuous or intermittent shedding, including at times conducive to transmission, such as calving (Lawson and others 1974, Richardson 1975, Nielsen and others 2004, Wray and Davies 2004).

ST infections in cattle have undergone a series of shifts in definitive phage-type (DT) isolated over the last forty years, with DT29 being superseded by DT204 complex, which was in turn superseded by DT104 (Rabsch and others 2001, 2002, Threlfall 2005). ST DT104 now seems to be in decline in cattle, pigs, poultry and humans in Great Britain (Davison and others 2005, 
VLA 2008). It is, however, still one of the most common specific ST phage types occurring in cattle (VLA 2010).

Counter to the classical epidemic and endemic patterns, prolonged herd infections with ST and short-lived infections with SD may also be observed. Environmental sampling on UK dairy farms over 16 months repeatedly yielded ST on one of the seven premises that were consistently Salmonella-positive (Davison and others 2005). Shedding of ST by cattle has been demonstrated for up to 18 months after initial clinical incidents on several farms, and shedding has been observed to reoccur on premises after a period when it was undetectable (Davies 1997).

Many aspects of herd management have been identified as relevant to the presence or persistence of bovine Salmonella infection; these principally emphasise larger herd size and poor biosecurity as major risk factors (Evans and Davies 1996, Evans 1996, Trueman and others 1996, Vaessen and others 1998, Davies 2001, Huston and others 2002, Boqvist and Vagsholm 2005, Fossler and others 2005, Davison and others 2006, Nielsen and others 2007, Vanselow and others 2007a). Another theme has been the potential for the recycling or acquisition of infection through the farm environment and/or via manure or effluent. Housing of cattle and exposure of calving cows to accommodation previously occupied by sick animals were risk factors in a UK study (Evans and Davies 1996). Sick pens, calving pens and manure stores may frequently be contaminated (Fossler and others 2005), and Salmonella may be imported with manure (Veling and others 2002, Vanselow and others 2007b). Poor control of rodents, wild birds and cats have also been identified as risks (Evans 1996, Veling and others 2002, Boqvist and Vagsholm 2005).

Patterns of infection appear to vary considerably between herds (Fossler and others 2004, Davison and others 2006). Attempts to model non-transient Salmonella herd infections need to take account of factors that contribute to forming epidemic or endemic patterns. It may be helpful to our understanding of such factors to trace both endemic and epidemic infections over time. Such monitoring would ideally include the prevalence and intensity of shedding among the various age and production groups on premises, plus the survival and dissemination of the organism in the environment and in wildlife.

The present study aimed to examine some of these parameters using intensive, longitudinal sampling of livestock management groups within a small number of previously-identified STand SD-affected farms. This complements previous UK longitudinal studies that were broader surveys across many farms or intensive observations of outbreaks associated with a single serovar. By focusing on ST and SD the intention was to include both endemic and epidemic infections.

\section{METHODS}

\section{Farm selection}

Dairy farms with recent incidents of clinical disease involving either ST DT104 or SD in cattle and which were accessible for intensive sampling from the Animal Health and Veterinary Laboratories Agency (AHVLA) site at Weybridge (Southeast England) were recruited. Once farmers had agreed to participate, visit dates were agreed. As it was the intention to sample herds where Salmonella infections were non-transient and not in a final phase, if the target serovar was not isolated at the first visit, the farm was removed from the 
study and an alternative farm was sought, using the above criteria. A questionnaire on herd size, management and recent medication was completed during the initial visit.

\section{Farm sampling}

Each farm was sampled approximately every six weeks (tables 2 and 3) for a period of 15 to 24 weeks (four to five visits in total). A stratified sampling approach was adopted, taking on each occasion up to 300 individual voided faecal pats that provided a representative spread across all management groups and ages of animals (i.e. dairy herd, calves, dry cows, heifers and bulls) present on the farm. In addition, naturally pooled faeces from collecting yards and slurry storage areas were collected. Faeces sampling in this fashion allowed repeated and noninvasive monitoring of each group of animals.

For each sample, a minimum of $100 \mathrm{~g}$ faeces was collected using a new disposable plastic glove and placed in a new plastic jar. Additional environmental samples taken were: dust, debris scraped from walls, bedding, feed, water from drinkers, pooled water, run-off and drainage water. Also, faeces from wild birds, rodents, other wildlife pests or animals in close association with the cattle were collected.

\section{Salmonella detection}

Samples were transported to the laboratory at ambient temperature, stored at $4{ }^{\circ} \mathrm{C}$ and cultured for Salmonella on the day of collection. Pre-enrichment in buffered peptone water (BPW) and culture on modified semi-solid Rappaport-Vassiliadis agar (MSRV; Difco 218681) then Rambach agar (Merck 107500) was performed, as described previously (Wales and others 2009).

If Salmonella was confirmed in the initial culture, the original samples (stored at $4{ }^{\circ} \mathrm{C}$ in their original containers) were subjected to enumeration of the pathogen using a dilutionenrichment (modified most-probable number) method when sufficient sample remained for testing. Up to 27 samples were enumerated per visit, this comprising all positive samples when fewer than 20 were available, or otherwise a subset representing all Salmonella-positive areas of the farm. Sample material ( $25 \mathrm{~g}$ ) was mixed with $225 \mathrm{ml} \mathrm{BPW} \mathrm{(preparation} \mathrm{'} 0$ '), and a $10 \mathrm{ml}$ aliquot of this (preparation ' 1 ') was separated and used to start a decimal dilution series in BPW. All preparations were incubated at $37^{\circ} \mathrm{C}$ for $16-20 \mathrm{~h}$. Preparations ' 0 ' and ' 1 ' were cultured using MSRV/Rambach as described above. All higher dilutions were stored at 4 ${ }^{\circ} \mathrm{C}$, then cultured if either of preparations ' 0 ' or ' 1 ' yielded Salmonella. The Salmonella count in the original sample was then estimated from the highest dilution in which Salmonella was isolated.

\section{Salmonella typing}

A proportion of isolates were serotyped at the AHVLA Salmonella Reference section. When the numbers of positive samples exceeded 15 per visit, a subset of isolates was chosen, representing each age group and area of the farm. Two ST strains isolated from farms which had been recruited as 'SD' farms were also phage-typed. 


\section{Statistical analyses}

Chi-square tests were used to compare unweighted proportions of Salmonella-positive samples, in various groups. Positive proportion ratio comparisons of Salmonella frequency between the major sampling strata were made within the SD and ST farm groups. Using only milking cow samples from both SD and ST farm groups, (this being the group with the largest dataset) a proportion of positive samples ratio comparison for isolating Salmonella from pooled versus individual samples was calculated. Confidence intervals were calculated and proportion ratio comparisons were performed using the EpiInfo statistical software package (http://www.cdc.gov/epiinfo/).

\section{RESULTS}

\section{Recruitment of farms}

Six suitable farms were visited initially, but from two of these the original serovar of interest (one each of SD and ST) could not be re-isolated. Two additional ST-positive farms were subsequently recruited, making a total of six study farms, three each with SD and ST infections, all within 180 miles from AHVLA Weybridge and separated from each other by a minimum of 18 miles. Details are given in Table 1.

\section{S. Dublin-infected farms}

The numbers of Salmonella-positive samples obtained are detailed in Table 2. Between 98 and 288 (median 170) individual bovine faeces samples and zero to 70 (median 20) pooled bovine faeces samples were taken per visit.

On Farm 1, the initial isolation of SD was made following a problem with abortions. SD was isolated from calves' faeces at visit 1 and was also associated mainly with calves at visit 2 . It was not isolated from the main dairy herd, and was not detected after visit 2. Other Salmonella serovars were isolated after visit 1 , collectively at a higher proportion than SD, These were: Agama, Ajiobo, Goldcoast, Newport, Saintpaul and Typhimurium (non-phage typable).

On Farm 2, the initial SD isolation had been from a sick cow, and at visit 1 the sick pen where this cow had been housed was still positive for SD in the lower layers of litter. At the same visit, SD was associated mainly with the calves, and was also found in rat faeces in the calf barn. Salmonella was infrequently isolated from this farm, and other serovars (Ajiobo, Binza and Kimuenza) individually were isolated at similar frequencies to SD.

On Farm 3, SD was the most prevalent serovar. It was isolated at each visit, mainly from the milking herd. Other serovars isolated were: Anatum, Agama, Enteritidis, Montevideo, Typhimurium DT104b, 3,10:-:1,6, O-rough and O-rough:g,p:-.

\section{S. Typhimurium-infected farms}

Initial isolates were all DT104. Representative isolates of ST obtained during the study were also DT104. The numbers of Salmonella-positive samples obtained from the visits to farms 4 to 6 are detailed in Table 3. Between 103 and 207 (median 152) individual bovine faeces samples and 14 to 67 (median 27) pooled bovine faeces samples were taken per visit. 
On Farm 4, ST was isolated from most areas, with the number of positive samples fluctuating substantially between visits. Only one non-ST isolate was found: $S$. Ajiobo from pet faeces, on the fifth visit.

On Farm 5, ST was first isolated from dry cows, but was found in most areas of the farm on all visits. The proportion of Salmonella-positive samples was high at each visit. At the first visit the only animal groups where Salmonella was not found were 40 bulling heifers and 20 calves, kept in a neighbour's field. The heifers were found to be positive for Salmonella at the third visit, after they had been moved back to the main farm. At the same visit the calving pen was found to be positive (included under 'in-calf heifers' in Table 3).

On Farm 6, ST was first isolated after the farmer noted a drop in milk yield. All groups of animals on the farm were infected during the study period. The proportion of positive samples declined over time, most markedly in the milking herd.

\section{Enumeration data}

Most (71\%) of the enumeration cultures were set up by one week after sample collection, and $90 \%$ and $100 \%$ were set up within 10 and 18 days, respectively. Following tabulation, (not shown), there was no general pattern discernable of decreasing maximum counts with sample storage time, and two of eight samples yielding $>10^{4} \mathrm{cfu}^{-\mathrm{g}^{-1}}$ had been stored for 18 days before processing. Results from the 302 samples identified as positive for the target serovar on the farm (SD or ST) are summarised in the Figure. Many of these enumeration cultures did not yield Salmonella, and these were allocated to the $<1$ to $10 \mathrm{cfu}^{-\mathrm{g}^{-1}}$ category, as they had previously been shown to be positive.

On each of farms 1 and 2, fewer than 10 enumerated samples proved to be SD-positive. Calves were the largest source of these, and they also produced the only samples exceeding 10 cfu.g ${ }^{-1}$. On Farm 3, 50 enumerated samples were positive for SD. These were mostly pooled or individual faecal samples from the milking herd.

On Farm 4, some of the individual samples from calves, milkers and dry cows had high counts of Salmonella, including up to $10^{7} \mathrm{cfu}^{-\mathrm{g}^{-1}}$ in two individual samples from dairy and dry cows. Farm 5 had a particularly large proportion of high-count samples on all visits, with some containing up to $10^{6} \mathrm{cfu} \cdot \mathrm{g}^{-1}$. The highest counts were in individual faecal samples from the milking herd. The counts of ST were lower on Farm 6 than on farms 4 and 5, as were the number of positive samples. The highest counts seen were in samples taken from calves.

Overall, the distribution of Salmonella counts was similar for both individual and pooled faeces samples, although the highest counts were only seen in individual samples. A similar fraction of individual and pooled faeces samples ( $80 \%$ and $75 \%$, respectively) fell into the $<1$ to $10 \mathrm{cfu} . \mathrm{g}^{-1}$ category. Likewise, $11 \%$ of individual and $13 \%$ of pooled faeces samples were in the $>10$ to $100 \mathrm{cfu}^{-\mathrm{g}^{-1}}$ category. However, no pooled samples exceeded $10^{4} \mathrm{cfu}^{\mathrm{g}} \mathrm{g}^{-1}$, whereas $2.4 \%$ of individual samples did, up to $10^{7} \mathrm{cfu}^{-\mathrm{g}^{-1}}$. On farms where maximum individual faeces counts did not exceed $10^{4}$ cfu. $\mathrm{g}^{-1}(1,2,3$ and 6$)$, pooled sample counts were heavily distributed towards the minimum of $<1$ to $10 \mathrm{cfu} \mathrm{g}^{-1}$, whereas on the two farms with higher individual faeces counts, the pooled sample counts were more widely distributed. 
Fifty-three of the 302 samples were not pooled or individual bovine faeces, but only three of these (effluent and manure from Farm 4 and pooled water from Farm 5) yielded counts exceeding $10 \mathrm{cfu} . \mathrm{g}^{-1}$. Four samples of faeces from badger latrines on farms 1 and 2 (not included in the main dataset illustrated in the Figure) yielded non-SD and non-ST serovars of Salmonella at levels between $10^{4}$ and $10^{6} \mathrm{cfu}_{\mathrm{g}} \mathrm{g}^{-1}$.

\section{Serovars other than Dublin or Typhimurium}

The non-SD serovars isolated from farms 1 to 3 were, in order of their frequency of identification: Ajiobo (30 isolates), Agama (22 isolates), Anatum (17 isolates), Binza (12 isolates) and Newport (eight isolates), with serovars Goldcoast, Kimuenza, Enteritidis, Montevideo, Saintpaul, Typhimurium, O rough, O rough:g,p:- and 3,10:-:1,6 being isolated between one and three times. By comparison, SD was identified 90 times from these farms (Table 5). It is likely that the O rough:g,p:- strains identified were SD, but insufficient serotyping information was available to demonstrate a definite identity. All $S$. Newport strains isolated were fully susceptible to the 16 antibiotics used in the VLA panel (VLA 2006). On two farms, faeces were collected from badger latrines: isolates of $S$. Agama, $S$. Ajiobo and $S$. Saintpaul were obtained from latrines on Farm 1 and $S$. Binza similarly from Farm 2.

The non-ST serovars isolated from farms 4 to 6 were: Ajiobo (one isolate), Durham (two isolates), O rough:i:1,2 (three isolates), and 4,5,12:-:1,2 (two isolates). The last two are likely to have been $S$. Typhimurium; however insufficient serotyping information was available to demonstrate a definite identity.

\section{Statistical analyses}

Proportion of positive samples. There was a highly significant $\left(\chi^{2}=942, \mathrm{P}<0.001\right)$ difference between the unweighted proportions of Salmonella positive samples from SD $(7.5 \%)$ versus ST (42\%) farms. There were similar differences between the two groups of farms when considering just the principal serovars, i.e. SD or ST (Table 4). For calves, SD was isolated from $3.1 \%$ of samples from 'SD' farms and ST from $50.6 \%$ of samples from 'ST' farms $\left(\chi^{2}=252, \mathrm{P}<0.001\right)$. For milking cows the equivalent statistics were $4.4 \%$ for SD and $46.3 \%$ for ST $\left(\chi^{2}=739, \mathrm{P}<0.001\right)$.

On SD-infected farms only, the proportion of SD-positive samples was highest among the milking herd at $4.4 \%$. Comparing $95 \%$ confidence intervals of ratios of the proportion of positive samples, and using the milking herd as the reference, the proportion in the milking herd was significantly higher than in other groups except calves (Table 4). The principal reason for this concentration in the milking cows was shedding of SD in this production group on Farm 3 (Table 2). For all serovars other than SD the proportion of positive samples ratio was similar among milking cows, calves and all other samples (data not shown). On STinfected farms the positive proportion ratios were not significantly different between milking cows and calves, but they were significantly lower among other cattle and the environment, compared with milking cows (Table 4). This is a similar pattern to that seen with the SD data, although for SD the difference between milking cows and other adult stock (i.e. not calves) was far more marked than with ST. 
Pooled versus individual samples. The proportion of positive samples ratio for detecting Salmonella in pooled compared with individual samples was 2.6 (95\% confidence interval $2.4-2.9)$.

\section{DISCUSSION}

The ST isolation frequencies among important production groups (calves and milking cows) on 'ST' farms were significantly higher than the equivalent SD isolation frequencies on 'SD' farms. The highest proportion of SD shedding was observed amongst calves, plus amongst milkers on Farm 3, whereas in ST-positive farms shedding was more evenly spread across all production groups. There was a particularly low frequency of isolation of SD from adult cattle not in the milking herd. Farm 3 was visited especially soon after identification of infection, which may account for the greater shedding of SD by milking cattle than on the other two SD farms, especially if the milking herd was the origin of the infection. Alternatively, management and/or hygiene factors may have predisposed that milking herd to frequent Salmonella shedding.

ST was dominant on farms 4 to 6 (in respect of proportion of positive samples, maximum counts and other serovar isolates) by contrast with SD on farms 1 to 3 . There may have been some 'masking' by ST of smaller numbers of other salmonellas through the enrichmentdetection process. Nonetheless, SD exhibits long-term latency in some animals and adaptation to periparturient transmission to calves and it is possible that these characteristics may allow endemic persistence but show relatively light environmental contamination alongside more transient infections by other serovars.

The Salmonella density in positive samples was typically ( $>65 \%$ of samples on all farms) below 10 cfu. ${ }^{-1}$, regardless of serovar. However, occasional samples contained much higher numbers of Salmonella, all from 'ST' herds. It may be that substantial amplification of the organism occurs in only a small proportion of animals. Such individuals may be epidemiologically highly significant, for example if the establishment of Salmonella infection within a group requires a certain threshold challenge dose. There is evidence, from other longitudinal studies of other serovars, of especially prolonged or heavy shedding of Salmonella by a minority of individuals (Jones and others 1983, Roy and others 2001, Van Kessel and others 2007), and such individuals can substantially affect outcomes in mathematical models of bovine Salmonella epidemiology (Lanzas and others 2008). It is unclear in the present study whether the heavily-shedding individuals were doing so transiently or persistently.

The high prevalence, and sometimes high density, of ST shedding seems likely to have promoted the rapid spread of infection within farms 4 to 6 , and to have increased the risk of the infection being carried off the premises. An 'epidemic' disease pattern would be expected in these circumstances. Conversely an 'endemic' pattern of infection may result if spread is limited and consequent immunity is patchy. This may happen if the level of shedding does not result in an infectious dose for much of the herd, or if groups are housed in different areas of the farm or on separate holdings. As a tentative hypothesis, this endemic pattern could be typical among adults with a less frequently-shed serovar such as SD. It may exceptionally be seen with a more heavily-shed serovar (such as ST) in the context of frequent introductions of immunologically naïve stock into the infected area. Mathematical models of Salmonella epidemiology in dairy herds (Xiao and others 2006, Lanzas and others 2008) lend support to 
the significance of such factors as the duration and intensity of shedding and the quality of immune response in the development of epidemic versus endemic infection patterns.

It may be that factors such as biosecurity, feeding, management and movement of young stock and parasite control influenced the various farms' Salmonella risk and subsequent epidemiology. Comprehensive risk factor modelling was outside the scope of the present study, but the suggested interplay between shedding levels, immunity, and the extent and duration of herd infections does not exclude other factors that may influence which serovar is likely to be present and how it may behave.

Temporal, weather, management and geographical effects also should be considered as explanatory factors. Despite sampling of SD farms starting, on average, earlier in the year and later after diagnosis than ST farms, no trend for a decreasing or increasing proportion of positive samples with time after initial isolation is evident, neither are peaks or troughs of positive samples seen in concert with hotter (summer) or colder (late autumn) seasons. There were no marked differences in climate or geography within the study area. Thus, gross influences of the above factors are not evident, although fuller evaluation of such potential effects would require a larger study.

Spatial and temporal clustering of dairy herd infections with SD, and potentially with ST, has been reported in the UK (Fenton and others 2009). It is therefore possible that strain relatedness within the same serovars on different farms partly accounts for the differences observed between the serovars. i.e. there was a selection bias towards closely-related strains within each serovar. Certain strains of SD have proved difficult to culture from the faeces of certain cattle(Baggesen and others 2007), and it is certainly possible that related SD strains might be responsible for the infrequent isolations of SD on the three different premises. However, the higher proportion of positive samples seen in specific management groups suggest otherwise.

Salmonella vaccination immediately preceded a dramatic reduction in shedding in one instance: the milking herd of Farm 6, vaccinated between visits 1 and 2. However, the dry cows on the same farm and the adult stock on farms 4 and 5 did not show a similar drop in shedding following vaccination. This suggests that vaccination had, at best, a variable effect on shedding. This contrasts with a previous report, where a rapid reduction in the shedding of ST DT104 and its long-term cessation on several closed dairy farms was associated with the use of a killed SD/ST vaccine (Davies 1997).

Besides the target serovars, all named serovars isolated in the present study have been detected in diagnostic or environmental samples from British cattle in recent years (Davison and others 2006, VLA 2008, Carrique-Mas and others 2010). On some of the six farms there were serovars common to cattle and wildlife, some of which are not often cattle-associated. Some of these have been associated in the past with badgers, including Binza, Agama, Anatum, Durham and Ajiobo (Wray and others 1977, Wilson and others 2003, R. H. Davies, unpublished). Serovars Goldcoast, Kimuenza, Newport and Anatum have also previously been isolated from wildlife, while Montevideo has been associated with sheep and animal feed (VLA 2008). The repeated isolation of ST DT104 from wildlife is consistent with previous investigations (Davies 1997), where ST DT104 persisted in swallows and mice after disappearing from the herd and its direct environment. 
The high density of Salmonella found in some badger faecal samples in the current study is evidence of the reinfection risk that badgers may pose. Fortunately the badger-associated serovars are not currently major public health threats, but earlier VLA investigations on highly-contaminated premises (Davies 1997, VLA unpublished data) have shown that badgers can be infected with ST DT104, and with $S$. Goldcoast that had been associated with human disease.

The present MSRV Salmonella culture method appears, unusually, to be generally sensitive and specific when used with environmental samples and with cattle faeces, including those containing SD (Baggesen and others 2007, Eriksson and Aspan 2007, Carrique-Mas and Davies 2008). However even the MSRV method shows unpredictably low sensitivity with certain combinations of faeces and SD (Baggesen and others 2007), which should be borne in mind when interpreting the present data. The comparison made between individual and pooled samples supports the value of pooling when sensitive Salmonella detection is used, as previously reported with cattle and pig faeces (Kivela and others 1999, Arnold and Cook 2009).

In summary, the present study examined two Salmonella serovars (SD and ST), classically associated with different patterns of bovine infection, on a small number of farms. Distinct patterns were associated with each serovar, both in the intensity of faecal shedding and in the livestock groups most affected. Among the study herds, ST DT104 affected all parts of a farm including wildlife, and was shed by a higher proportion of cattle, and in higher numbers than was SD. This, and the development of herd immunity, could help to partially explain the epidemic potential of ST as well as the subsequent clearance of infection, in an industry where movements of potential short- or long-term carrier animals are frequent and biosecurity measures are relatively poor or difficult to apply.

\section{Acknowledgements}

We would like to thank the farmers who participated in this study.

\section{Funding}

This study was funded by the UK Department for Environment, Food and Rural Affairs, United Kingdom, under project OZ0318. 


\section{References}

AHVLA (2011) Salmonella in livestock production in GB 2010. A. H. a. V. L. Agency. Weybridge, UK, AHVLA publications. http://vla.defra.gov.uk/reports/rep_salm rep10.htm Accessed 10th Ocober 2011

ARNOLD, M. E. \& COOK, A. J. C. (2009) Estimation of sample sizes for pooled faecal sampling for detection of Salmonella in pigs. Epidemiology and Infection 137, 1734-1741

BAGGESEN, D. L., NIELSEN, L. R., SORENSEN, G., BODKER, R. \& ERSBOLL, A. K. (2007) Growth inhibitory factors in bovine faeces impairs detection of Salmonella Dublin by conventional culture procedure. Journal of Applied Microbiology 103, 650-656

BOQVIST, S. \& VAGSHOLM, I. (2005) Risk factors for hazard of release from Salmonella-control restriction on Swedish cattle farms from 1993 to 2002. Preventive Veterinary Medicine 71, 35-44

CARRIQUE-MAS, J. \& DAVIES, R. H. (2008) Sampling and bacteriological detection of Salmonella in poultry and poultry premises: a review. Revue Scientifique et Technique de l'Office International Des Epizooties 27, 665-677

CARRIQUE-MAS, J. J., WILLMINGTON, J. A., PAPADOPOULOU, C., WATSON, E. N. \& DAVIES, R. H. (2010) Salmonella infection in cattle in Great Britain, 2003 to 2008. Veterinary Record 167, 560-565

DAVIES, R. (2001) Salmonella typhimurium DT104: has it had its day? In Practice 23, 342-351

DAVIES, R. H. (1997) A two year study of Salmonella typhimurium DT 104 infection and contamination on cattle farms. Cattle Practice 5, 189-194

DAVISON, H. C., SAYERS, A. R., SMITH, R. P., PASCOE, S. J. S., DAVIES, R. H., WEAVER, J. P. \& EVANS, S. J. (2006) Risk factors associated with the salmonella status of dairy farms in England and Wales. Veterinary Record 159, 871-880

DAVISON, H. C., SMITH, R. P., PASCOE, S. J. S., SAYERS, A. R., DAVIES, R. H., WEAVER, J. P., KIDD, S. A., DALZIEL, R. W. \& EVANS, S. J. (2005) Prevalence, incidence and geographical distribution of serovars of Salmonella on dairy farms in England and Wales. Veterinary Record 157, 703-711

ERIKSSON, E. \& ASPAN, A. (2007) Comparison of culture, ELISA and PCR techniques for Salmonella detection in faecal samples for cattle, pig and poultry. BMC Veterinary Research 3, 21

EVANS, S. \& DAVIES, R. (1996) Case control study of multiple-resistant Salmonella typhimurium DT104 infection of cattle in Great Britain. Veterinary Record 139, 557-558

EVANS, S. J. (1996) A case control study of multiple resistant Salmonella Typhimurium DT 104 infection of cattle in Great Britain. Cattle Practice 4, 259-263 
FENTON, S. E., CLOUGH, H. E., DIGGLE, P. J., EVANS, S. J., DAVISON, H. C., VINK, W. D. \& FRENCH, N. P. (2009) Spatial and spatio-temporal analysis of Salmonella infection in dairy herds in England and Wales. Epidemiology and Infection 137, 847-857

FOSSLER, C. P., WELLS, S. J., KANEENE, J. B., RUEGG, P. L., WARNICK, L. D., BENDER, J. B., GODDEN, S. M., HALBERT, L. W., CAMPBELL, A. M. \& ZWALD, A. M. G. (2004) Prevalence of Salmonella spp on conventional and organic dairy farms. Journal of the American Veterinary Medical Association 225, 567-573

FOSSLER, C. P., WELLS, S. J., KANEENE, J. B., RUEGG, P. L., WARNICK, L. D., EBERLY, L. E., GODDEN, S. M., HALBERT, L. W., CAMPBELL, A. M., BOLIN, C. A. \& ZWALD, A. M. G. (2005) Cattle and environmental sample-level factors associated with the presence of Salmonella in a multi-state study of conventional and organic dairy farms. Preventive Veterinary Medicine 67, 39-53

HUSTON, C. L., WITTUM, T. E., LOVE, B. C. \& KEEN, J. E. (2002) Prevalence of fecal shedding of Salmonella spp in dairy herds. Journal of the American Veterinary Medical Association 220, 645649

JONES, P. W., COLLINS, P., BROWN, G. T. \& AITKEN, M. M. (1983) Salmonella saint-paul infection in two dairy herds. Journal of Hygiene 91, 243-257

JONES, P. W., WATSON, P. R. \& WALLIS, T. S. (2004) Salmonellosis. In Bovine Medicine Diseases and Husbandry of Cattle. 2nd edn. Eds A. H. Andrews, R. W. Blowey, H. Boyd, R. G. Eddy. Oxford, Blackwell Science Ltd. pp 215-230

KIVELA, S. L., RUOHO, O., SEUN, E. \& HINTIKKA, E. L. (1999) Pooled faecal samples compared with individual samples for detection of Salmonella in cattle. Bovine Practitioner 33, 74-75

LANZAS, C., BRIEN, S., IVANEK, R., LO, Y., CHAPAGAIN, P. P., RAY, K. A., AYSCUE, P., WARNICK, L. D. \& GROHN, Y. T. (2008) The effect of heterogeneous infectious period and contagiousness on the dynamics of Salmonella transmission in dairy cattle. Epidemiology and Infection 136, 1496-1510

LAWSON, G. H. K., MCPHERSON, E. A., LAING, A. H. \& WOODING, P. (1974) Epidemiology of Salmonella Dublin infection in a dairy herd: 1. Excretion and persistence of organism. Journal of Hygiene 72, 311-328

NIELSEN, L. R., SCHUKKEN, Y. H., GROHN, Y. T. \& ERSBOLL, A. K. (2004) Salmonella Dublin infection in dairy cattle: risk factors for becoming a carrier. Preventive Veterinary Medicine 65, 47-62

NIELSEN, L. R., WARNICK, L. D. \& GREINER, M. (2007) Risk factors for changing test classification in the Danish surveillance program for Salmonella in dairy herds. Journal of Dairy Science 90, 2815-2825

PRADHAN, A. K., VAN KESSEL, J. S., KARNS, J. S., WOLFGANG, D. R., HOVINGH, E., NELEN, K. A., SMITH, J. M., WHITLOCK, R. H., FYOCK, T., LADELY, S., FEDORKA-CRAY, P. J. \& SCHUKKEN, Y. H. (2009) Dynamics of endemic infectious diseases of animal and human importance on three dairy herds in the northeastern United States. Journal of Dairy Science 92, 18111825 
RABSCH, W., ANDREWS, H. L., KINGSLEY, R. A., PRAGER, R., TSCHAPE, H., ADAMS, L. G. \& BAUMLER, A. J. (2002) Salmonella enterica serotype Typhimurium and its host-adapted variants. Infection and Immunity 70, 2249-2255

RABSCH, W., TSCHAPE, H. \& BAUMLER, A. J. (2001) Non-typhoidal salmonellosis: emerging problems. Microbes and Infection 3, 237-247.

RICHARDSON, A. (1975) Salmonellosis in Cattle. Veterinary Record 96, 329-331

ROY, R., HIGGINS, R., FORTIN, M. \& TARDIF, S. (2001) Salmonella Give infection in 2 dairy herds. Canadian Veterinary Journal-Revue Veterinaire Canadienne 42, 468-470

STERNBERG, S., JOHNSSON, A., ASPAN, A., BERGSTRÖM, K., KALLAY, T. B. \& SZANTO, E. (2008) Outbreak of Salmonella Thompson infection in a Swedish dairy herd. Veterinary Record 163, 596-599

THRELFALL, E. J. (2005) Drug resistance in Salmonella and Shigella. In Frontiers in antibiotic resistance: A tribute to Stuart B. Levy. Eds D. G. White, M. N. Alekshun, P. F. McDermott. Washington, DC, ASM Publications

TRUEMAN, K. F., THOMAS, R. J., MACKENZIE, A. R., EAVES, L. E. \& DUFFY, P. F. (1996) Salmonella Dublin infection in Queensland dairy cattle. Australian Veterinary Journal 74, 367-369

VAESSEN, M. A., VELING, J., FRANKENA, K., GRAAT, E. A. M. \& KLUNDER, T. (1998) Risk factors for Salmonella dublin infection on dairy farms. Veterinary Quarterly 20, 97-99

VAN KESSEL, J. S., KARNS, J. S., WOLFGANG, D. R., HOVINGH, E. \& SCHUKKEN, Y. H. (2007) Longitudinal study of a clonal, subclinical outbreak of Salmonella enterica subsp. enterica serovar Cerro in a U.S. dairy herd. Foodborne Pathogens and Disease 4, 449-461

VANSELOW, B. A., HORNITZKY, M. A., WALKER, K. H., EAMENS, G. J., BAILEY, G. D., GILL, P. A., COATES, K., CORNEY, B., CRONIN, J. P. \& RENILSON, S. (2007a) Salmonella and on-farm risk factors in healthy slaughter-age cattle and sheep in eastern Australia. Australian Veterinary Journal 85, 498-502

VANSELOW, B. A., HUM, S., HORNITZKY, M. A., EAMENS, G. J. \& QUINN, K. (2007b) Salmonella Typhimurium persistence in a Hunter Valley dairy herd. Australian Veterinary Journal $\mathbf{8 5}$, 446-450

VELING, J., WILPSHAAR, H., FRANKENA, K., BARTELS, C. \& BARKEMA, H. W. (2002) Risk factors for clinical Salmonella enterica subsp enterica serovar Typhimurium infection on Dutch dairy farms. Preventive Veterinary Medicine 54, 157-168

VLA (2006) Salmonella in livestock production in GB 2005. Veterinary Laboratories Agency. http://www.defra.gov.uk/vla/reports/rep_salm_rep05.htm Accessed 27th March 2012

VLA (2008) Salmonella in livestock production in GB 2007. Veterinary Laboratories Agency. http://www.defra.gov.uk/vla/reports/rep_salm rep07.htm Accessed 27th March 2012 
VLA (2010) Salmonella in livestock production in GB 2009. Veterinary Laboratories Agency. http://vla.defra.gov.uk/reports/rep_salm_rep09.htm Accessed 27th March 2012

WALES, A. D., MCLAREN, I. M., BEDFORD, S., CARRIQUE-MAS, J. J., COOK, A. J. C. \& DAVIES, R. H. (2009) Longitudinal survey of the occurrence of Salmonella in pigs and the environment of nucleus breeder and multiplier pig herds in England. Veterinary Record 165, 648-657

WILSON, J. S., HAZEL, S. M., WILLIAMS, N. J., PHIRI, A., FRENCH, N. P. \& HART, C. A. (2003) Nontyphoidal salmonellae in United Kingdom badgers: prevalence and spatial distribution. Applied and Environmental Microbiology 69, 4312-4315

WRAY, C., BAKER, K., GALLAGHER, J. \& NAYLOR, P. (1977) Salmonella infection in badgers in the South West of England. British Veterinary Journal 133, 526-529

WRAY, C. \& DAVIES, R. (2004) Salmonella in cattle: update. Cattle Practice 12, 313-316

WRAY, C., WADSWORTH, Q. C., RICHARDS, D. W. \& MORGAN, J. H. (1989) A three-year study of Salmonella dublin infection in a closed dairy herd. Veterinary Record 124, 532-537

XIAO, Y., CLANCY, D., FRENCH, N. P. \& BOWERS, R. G. (2006) A semi-stochastic model for Salmonella infection in a multi-group herd. Mathematical Biosciences 200, 214-233 
Table 1: Details of the six dairy farms studied

\begin{tabular}{|c|c|c|c|c|c|c|}
\hline & Farm 1 & Farm 2 & Farm 3 & Farm 4 & Farm 5 & Farm 6 \\
\hline $\begin{array}{l}\text { Original } \\
\text { isolate (date) }\end{array}$ & $\begin{array}{l}S . \text { Dublin } \\
(03 / 03 / 05)\end{array}$ & $\begin{array}{l}S . \text { Dublin } \\
(20 / 05 / 05)\end{array}$ & $\begin{array}{l}S . \text { Dublin } \\
(01 / 03 / 05)\end{array}$ & $\begin{array}{l}S . \text { Typhimurium } \\
(01 / 06 / 05)\end{array}$ & $\begin{array}{l}S . \text { Typhimurium } \\
(29 / 06 / 05)\end{array}$ & $\begin{array}{l}S . \text { Typhimurium } \\
(23 / 08 / 05)\end{array}$ \\
\hline $\begin{array}{l}\text { Days to first } \\
\text { sampling }\end{array}$ & 98 & 28 & 105 & 20 & 56 & 9 \\
\hline Farm size * & $\begin{array}{lr}\text { Dairy herd } & \mathbf{2 7 0} \\
\text { Calves }<6 \text { mths }^{\dagger} & \mathbf{8 0} \\
\text { Bulling heifers } & \mathbf{5 4} \\
\text { Bull beef } & \mathbf{4}\end{array}$ & $\begin{array}{lr}\text { Dairy herd } & \mathbf{1 7 1} \\
\text { Calves }<11 \text { mths }^{\dagger} & \mathbf{1 0 0} \\
\text { Bullocks } & \mathbf{1 1} \\
\text { Bulls } & \mathbf{2}\end{array}$ & 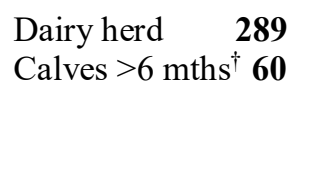 & $\begin{array}{lr}\text { Milking } & \mathbf{3 0 0} \\
\text { Calves } & \mathbf{8 0 - 1 0 0}\end{array}$ & $\begin{array}{ll}\text { Dairy herd } & \mathbf{1 5 0} \\
\text { Calves } & \mathbf{1 0 0}\end{array}$ & $\begin{array}{l}\text { Dairy herd } \quad \mathbf{2 7 0} \\
\text { Calves/young } \mathbf{1 9 0} \\
\text { stock } 8 \text { months } \\
\text { to } 2 \text { years }\end{array}$ \\
\hline Closed herd & No & Yes & No & No & Yes & No \\
\hline $\begin{array}{l}\text { Rear own } \\
\text { replacements }\end{array}$ & & & Yes & Yes & Yes & \\
\hline $\begin{array}{l}\text { Brought in } \\
\text { stock }\end{array}$ & $\begin{array}{l}\text { Calves } \\
\text { In-calf heifers }\end{array}$ & & $\begin{array}{l}\text { Virgin bulls } \\
\text { Young stock }\end{array}$ & $\begin{array}{l}\text { Bulls } \\
\text { Young stock }\end{array}$ & & $\begin{array}{l}3 \% \text { brought in } \\
\text { (Heifers) }\end{array}$ \\
\hline $\begin{array}{l}\text { Treatment of } \\
\text { new stock }\end{array}$ & $\begin{array}{l}\text { New calves mixed } \\
\text { immediately. In-calf } \\
\text { heifers separate. }\end{array}$ & & Mixed after 1 week & Mixed immediately & & Mixed immediately \\
\hline $\begin{array}{l}\text { Salmonella } \\
\text { vaccination }\end{array}$ & $\begin{array}{l}\text { Calves } \\
\text { (Bovivac } \mathrm{S}^{\star} \text { ) }\end{array}$ & No & $\begin{array}{l}\text { Last } 100 \text { cows calved } \\
\text { plus young stock } \\
\text { (Bovivac } S^{\dagger} \text { ) }\end{array}$ & $\begin{array}{l}50 \text { dry cows: } 2 \text { doses } \\
20 \text { days apart. } \\
\text { All stock by } 2^{\text {nd }} \text { visit } \\
\text { (Bovivac } S^{\ddagger} \text { ) }\end{array}$ & $\begin{array}{l}\text { All existing stock in } \\
\text { June \& July. New } \\
\text { calves not vaccinated. } \\
\text { (Bovivac } \mathrm{S}^{\ddagger} \text { ) }\end{array}$ & $\begin{array}{l}\text { Dairy herd, dry cows } \\
\& \text { in-calf heifers, } 1^{\text {st }} \\
\text { dose early Sept } \\
\text { (Bovivac } S^{\ddagger} \text { ) }\end{array}$ \\
\hline $\begin{array}{l}\text { Antibiotic } \\
\text { treatment in } \\
\text { last } 3 \text { months }\end{array}$ & $\begin{array}{l}\text { Injections (calves \& } \\
\text { adults), intramammary } \\
\text { and oral (adults). }\end{array}$ & $\begin{array}{l}\text { Marbofloxacin for sick } \\
\text { animals }\end{array}$ & $\begin{array}{l}\text { Any sick adults or } \\
\text { young stock treated. }\end{array}$ & Oxytetracycline given & $\begin{array}{l}\text { Marbofloxacin given } \\
\text { to Salmonella cases }\end{array}$ & $\begin{array}{l}\text { Marbofloxacin given } \\
\text { to Salmonella cases }\end{array}$ \\
\hline $\begin{array}{l}\text { Other animals } \\
\text { on farm }\end{array}$ & Dog, Pig & Dog, Horse, Pig & Dog, Pig & Dog & Cat, Dog & $\begin{array}{l}\text { Chicken, Dog, Horse, } \\
\text { Sheep, Guinea Fowl }\end{array}$ \\
\hline $\begin{array}{l}\text { Wildlife } \\
\text { problems }\end{array}$ & Badger, Rat & Badger, Rat, Rabbit & Bird, Fox, Rat & Bird & Bird & Bird, Rat \\
\hline
\end{tabular}

* Numbers of animals in various management categories are given. ${ }^{\dagger}$ Months. *Inactivated, adjuvanted combined Salmonella Dublin and Salmonella Typhimurium vaccine, Intervet Schering-Plough Animal Health. Administration reportedly as per data sheet (two doses 3 weeks apart for adults and 2-3 weeks apart for calves). 
Table 2: All Salmonella isolates from farms with original isolates of Salmonella Dublin

\begin{tabular}{|c|c|c|c|c|c|c|c|c|c|c|c|c|c|}
\hline \multirow[b]{3}{*}{ Sample category } & \multicolumn{13}{|c|}{ No. of positives / total samples } \\
\hline & \multicolumn{4}{|l|}{ Farm 1} & \multicolumn{4}{|l|}{ Farm 2} & \multicolumn{5}{|l|}{ Farm 3} \\
\hline & $\begin{array}{l}\text { Visit } 1 \\
09 / 06 / 05\end{array}$ & $\begin{array}{l}\text { Visit } 2 \\
26 / 07 / 05\end{array}$ & $\begin{array}{l}\text { Visit } 3 \\
05 / 09 / 05\end{array}$ & $\begin{array}{l}\text { Visit } 4 \\
18 / 10 / 05\end{array}$ & $\begin{array}{l}\text { Visit } 1 \\
17 / 06 / 05\end{array}$ & $\begin{array}{l}\text { Visit } 2 \\
10 / 08 / 05\end{array}$ & $\begin{array}{l}\text { Visit } 3 \\
20 / 09 / 05\end{array}$ & $\begin{array}{l}\text { Visit } 4 \\
25 / 10 / 05\end{array}$ & $\begin{array}{l}\text { Visit } 1 \\
14 / 06 / 05\end{array}$ & $\begin{array}{l}\text { Visit } 2 \\
02 / 08 / 05\end{array}$ & $\begin{array}{l}\text { Visit } 3 \\
19 / 09 / 05\end{array}$ & $\begin{array}{l}\text { Visit } 4 \\
01 / 11 / 05\end{array}$ & $\begin{array}{l}\text { Visit } 5 \\
29 / 11 / 05\end{array}$ \\
\hline Milkers & $\mathbf{3}^{\mathrm{T}} / 120$ & $6 / 59$ & $13 / 86$ & $29 / 134$ & $\mathbf{5} / 88$ & $\mathbf{1}^{\mathrm{D}} / 80$ & $0 / 125$ & $\mathbf{1}^{\mathrm{D}} / 100$ & $\mathbf{8}^{\mathrm{D}} / 217$ & $22^{\mathrm{D}, \mathrm{T}} / 129$ & $11^{\mathrm{D}} / 169$ & $36^{\mathrm{D}} / 158$ & $2^{\mathrm{D}} / 133$ \\
\hline (pooled samples)* & & $(9)$ & $(24)$ & $(37)$ & & $(20)$ & $(14)$ & $(29)$ & $(9)$ & (19) & $(24)$ & $(33)$ & $(31)$ \\
\hline Dry cows & & & & & $6 / 22$ & $0 / 37$ & $0 / 20$ & $0 / 19$ & & & & & $0 / 19$ \\
\hline $\begin{array}{l}\text { In-calf heifers } \\
\quad \text { (pooled samples)* }\end{array}$ & & $1^{\mathrm{D}} / 7$ & & & & & & & & & & & $\begin{array}{l}0 / 20 \\
(20)\end{array}$ \\
\hline $\begin{array}{l}\text { Bulling heifers } \\
\qquad \text { (pooled samples)* }\end{array}$ & & & & & & & & & & & & & $\begin{array}{l}0 / 19 \\
(19)\end{array}$ \\
\hline Heifers & & & & & $0 / 18$ & $0 / 19$ & $2 / 30$ & & $0 / 40$ & $3 / 80$ & $2 / 40$ & $0 / 3$ & $0 / 1$ \\
\hline Calves & $9^{\mathrm{D}} / 78$ & $6^{\mathrm{D}} / 41$ & $10 / 37$ & & $2^{\mathrm{D}} / 26$ & $\mathbf{1}^{\mathrm{D}} / 49$ & $0 / 30$ & $0 / 58$ & $\mathbf{1}^{\mathrm{D}} / 40$ & $0 / 34$ & $\mathbf{1}^{\mathrm{D}} / 45$ & $0 / 41$ & \\
\hline Bulls / bullocks & & & $0 / 6$ & $1 / 3$ & $0 / 10$ & & $0 / 10$ & $0 / 1$ & & & & & \\
\hline Mixed bovine areas & & & & $2 / 70$ & & & & & & & & & \\
\hline Non-bovine stock & & $0 / 3$ & & $0 / 1$ & & & & $0 / 1$ & $0 / 8$ & $0 / 5$ & $0 / 9$ & $0 / 2$ & \\
\hline Environmental & $3 / 32$ & $2^{\mathrm{D}} / 17$ & $1 / 15$ & $1 / 15$ & $\mathbf{1}^{\mathrm{D}} / 23$ & $0 / 17$ & $1 / 9$ & $0 / 6$ & $\mathbf{1}^{\mathrm{D}} / 14$ & $2 / 27$ & $0 / 11$ & $\mathbf{8}^{\mathrm{D}} / 30$ & $2 / 23$ \\
\hline Wildlife & $0 / 2$ & $0 / 4$ & $3 / 8$ & $2 / 5$ & $3^{\mathrm{D}} / 9$ & $\mathbf{1}^{\mathrm{D}} / 9$ & $1 / 11$ & $0 / 2$ & $0 / 1$ & $0 / 3$ & $0 / 4$ & $0 / 4$ & $0 / 3$ \\
\hline Pets (incl. horses) & & $2 / 2$ & $0 / 2$ & & $1 / 3$ & & $0 / 3$ & & & $0 / 1$ & $0 / 1$ & & \\
\hline Feed in storage & & $0 / 1$ & & $0 / 1$ & & $0 / 6$ & $0 / 2$ & $0 / 3$ & & & & $0 / 2$ & $0 / 1$ \\
\hline Totals: fraction & $15 / 232$ & $17 / 134$ & $27 / 154$ & $35 / 229$ & $18 / 199$ & $3 / 217$ & $4 / 240$ & $\mathbf{1} / 190$ & $10 / 320$ & $27 / 279$ & $14 / 279$ & $44 / 240$ & $4 / 219$ \\
\hline$\%$ positive & 6.5 & 12.7 & 17.5 & 15.3 & 9.0 & 1.4 & 1.7 & 0.5 & 3.1 & 9.7 & 5.0 & 18.3 & 1.8 \\
\hline
\end{tabular}

* Number of samples, included in total, made up of pooled faeces from communal areas.

D Salmonella Dublin isolated. ${ }^{\mathrm{T}}$ Salmonella Typhimurium isolated. 
Table 3: All Salmonella isolates from farms with original isolates of Salmonella Typhimurium

\begin{tabular}{|c|c|c|c|c|c|c|c|c|c|c|c|c|c|}
\hline \multirow[b]{3}{*}{ Sample category } & \multicolumn{13}{|c|}{ No. of positives / total samples } \\
\hline & \multicolumn{5}{|l|}{ Farm 4} & \multicolumn{4}{|l|}{ Farm 5} & \multicolumn{4}{|l|}{ Farm 6} \\
\hline & $\begin{array}{l}\text { Visit } 1 \\
21 / 06 / 05\end{array}$ & $\begin{array}{l}\text { Visit } 2 \\
16 / 08 / 05\end{array}$ & $\begin{array}{l}\text { Visit } 3 \\
27 / 09 / 05\end{array}$ & $\begin{array}{l}\text { Visit } 4 \\
09 / 11 / 05\end{array}$ & $\begin{array}{l}\text { Visit } 5 \\
05 / 12 / 05\end{array}$ & $\begin{array}{l}\text { Visit } 1 \\
24 / 08 / 05\end{array}$ & $\begin{array}{l}\text { Visit } 2 \\
04 / 10 / 05\end{array}$ & $\begin{array}{l}\text { Visit } 3 \\
\text { 15/11/05 }\end{array}$ & $\begin{array}{l}\text { Visit } 4 \\
13 / 12 / 05\end{array}$ & $\begin{array}{l}\text { Visit } 1 \\
01 / 09 / 05\end{array}$ & $\begin{array}{l}\text { Visit } 2 \\
11 / 10 / 05\end{array}$ & $\begin{array}{l}\text { Visit } 3 \\
23 / 11 / 05\end{array}$ & $\begin{array}{l}\text { Visit } 4 \\
16 / 12 / 05\end{array}$ \\
\hline $\begin{array}{l}\text { Milkers } \\
\qquad \text { (pooled samples)* }\end{array}$ & $\begin{array}{l}112^{\mathrm{T}} / 179 \\
(40)\end{array}$ & $\begin{array}{l}27^{\mathrm{T}} / 154 \\
(37)\end{array}$ & $\begin{array}{l}94^{\mathrm{T}} / 145 \\
(52)\end{array}$ & $\begin{array}{l}\mathbf{4 5}^{\mathrm{T}} / 121 \\
(20)\end{array}$ & $\mathbf{5 4}^{\mathrm{T}} / 133$ & $\begin{array}{l}\mathbf{6 6}^{\mathrm{T}} / 107 \\
(27)\end{array}$ & $\begin{array}{l}\mathbf{1 0 5}^{\mathrm{T}} / 149 \\
(67)\end{array}$ & $\begin{array}{l}\mathbf{7 8}^{\mathrm{T}} / 109 \\
(18)\end{array}$ & $\begin{array}{l}\mathbf{8 8}^{\mathrm{T}} / 111 \\
(20)\end{array}$ & $\begin{array}{l}\mathbf{5 9}^{\mathrm{T}} / 97 \\
(20)\end{array}$ & $\begin{array}{l}9^{\mathrm{T}} / 103 \\
(40)\end{array}$ & $\begin{array}{l}\mathbf{3}^{\mathrm{T}} / 101 \\
(20)\end{array}$ & $\begin{array}{l}7^{\mathrm{T}} / 106 \\
(20)\end{array}$ \\
\hline $\begin{array}{l}\text { Dry cows } \\
\qquad \text { (pooled samples)* }\end{array}$ & $\mathbf{1 1}^{\mathrm{T}} / 17$ & & $\mathbf{5}^{\mathrm{T}} / 8$ & $\mathbf{4}^{\mathrm{T}} / 36$ & $\begin{array}{l}9^{T} / 36 \\
(14)\end{array}$ & $\mathbf{2 1}^{\mathrm{T}} / 39$ & & & & $13^{\mathrm{T}} / 14$ & $\mathbf{2 2}^{\mathrm{T}} / 24$ & $2^{\mathrm{T}} / 39$ & $0 / 20$ \\
\hline In-calf heifers & & $3^{\mathrm{T}} / 12$ & & & & & $0 / 5$ & $\mathbf{3}^{\mathrm{T}} / 5$ & $0 / 2$ & & & & \\
\hline Bulling heifers & $0 / 19$ & & & & & & & & & $\mathbf{1}^{\mathrm{T}} / 40$ & & & \\
\hline $\begin{array}{l}\text { Heifers } \\
\qquad \text { (pooled samples)* }\end{array}$ & & $\mathbf{1}^{\mathrm{T}} / 38$ & & & & $0 / 40$ & & $\begin{array}{l}11^{\mathrm{T}} / 30 \\
(19)\end{array}$ & $\begin{array}{l}19^{\mathrm{T}} / 22 \\
(16)\end{array}$ & $2^{\mathrm{T}} / 14$ & & & \\
\hline $\begin{array}{l}\text { Calves } \\
\qquad \text { (pooled samples)* }\end{array}$ & $\mathbf{2 6}^{\mathrm{T}} / 30$ & $\mathbf{2 0}^{\mathrm{T}} / 40$ & $\mathbf{2 6}^{\mathrm{T}} / 29$ & $\mathbf{1 0}^{\mathrm{T}} / 31$ & $7^{\mathrm{T}} / 31$ & $\mathbf{8}^{\mathrm{T}} / 32$ & $\mathbf{1} 7^{\mathrm{T}} / 36$ & $\begin{array}{l}\mathbf{2 3} 3^{\mathrm{T}} / 25 \\
(4)\end{array}$ & $\begin{array}{l}\mathbf{1 8}^{\mathrm{T}} / 28 \\
(1)\end{array}$ & $\begin{array}{l}4^{\mathrm{T}} / 11 \\
(4)\end{array}$ & $\mathbf{8}^{\mathrm{T}} / 16$ & $7^{\mathrm{T}} / 19$ & $\mathbf{1}^{\mathrm{T}} / 16$ \\
\hline Bulls / bullocks & & & & & & & $\mathbf{8}^{\mathrm{T}} / 8$ & & & & & & \\
\hline Mixed bovine areas & & & & & & & $4^{\mathrm{T}} / 40$ & & & & & & \\
\hline Non-bovine stock & & & & & & & & & & & $\mathbf{1}^{\mathrm{T}} / 1$ & & $\mathbf{1}^{\mathrm{T}} / 4$ \\
\hline Environmental & $19^{\mathrm{T}} / 30$ & $\mathbf{1}^{\mathrm{T}} / 12$ & $\mathbf{8}^{\mathrm{T}} / 16$ & $\mathbf{9}^{\mathrm{T}} / 28$ & $4^{\mathrm{T}} / 20$ & $7^{\mathrm{T}} / 12$ & $4^{\mathrm{T}} / 15$ & $7^{\mathrm{T}} / 15$ & $9^{\mathrm{T}} / 14$ & $2^{\mathrm{T}} / 6$ & $\mathbf{8}^{\mathrm{T}} / 19$ & $0 / 9$ & $7^{\mathrm{T}} / 24$ \\
\hline Wildlife & $\mathbf{1}^{\mathrm{T}} / 3$ & & $0 / 2$ & $0 / 1$ & $0 / 2$ & $2^{\mathrm{T}} / 3$ & & & & $\mathbf{8}^{\mathrm{T}} / 12$ & $\mathbf{1}^{\mathrm{T}} / 3$ & $0 / 7$ & $3^{\mathrm{T}} / 7$ \\
\hline Pets (incl. horses) & $\mathbf{2}^{\mathrm{T}} / 2$ & $\mathbf{1}^{\mathrm{T}} / 3$ & $\mathbf{3}^{\mathrm{T}} / 6$ & $0 / 2$ & $1 / 4$ & $2^{\mathrm{T}} / 2$ & $2^{\mathrm{T}} / 3$ & $\mathbf{2}^{\mathrm{T}} / 2$ & $\mathbf{1}^{\mathrm{T}} / 2$ & $\mathbf{2}^{\mathrm{T}} / 2$ & $\mathbf{1}^{\mathrm{T}} / 5$ & $0 / 2$ & $0 / 3$ \\
\hline Feed in storage & & & & $0 / 1$ & & $0 / 2$ & $0 / 3$ & $0 / 2$ & $0 / 1$ & & & & \\
\hline Totals: fraction & $171 / 280$ & $\mathbf{5 3} / 259$ & $136 / 206$ & $68 / 220$ & $75 / 226$ & $106 / 237$ & $140 / 259$ & $124 / 188$ & $135 / 180$ & $91 / 196$ & $\mathbf{5 0} / 171$ & $12 / 177$ & $19 / 180$ \\
\hline$\%$ positive & 61.1 & 20.5 & 66.0 & 30.9 & 33.2 & 44.7 & 54.1 & 66.0 & 75.0 & 46.4 & 29.2 & 6.8 & 10.6 \\
\hline
\end{tabular}

*Number of samples, included in total, made up of pooled faeces from communal areas.

${ }^{\mathrm{T}}$ Salmonella Typhimurium isolated. 
Table 4: Comparisons between sampling categories of the proportion of samples positive for Salmonella serovars Dublin and Typhimurium

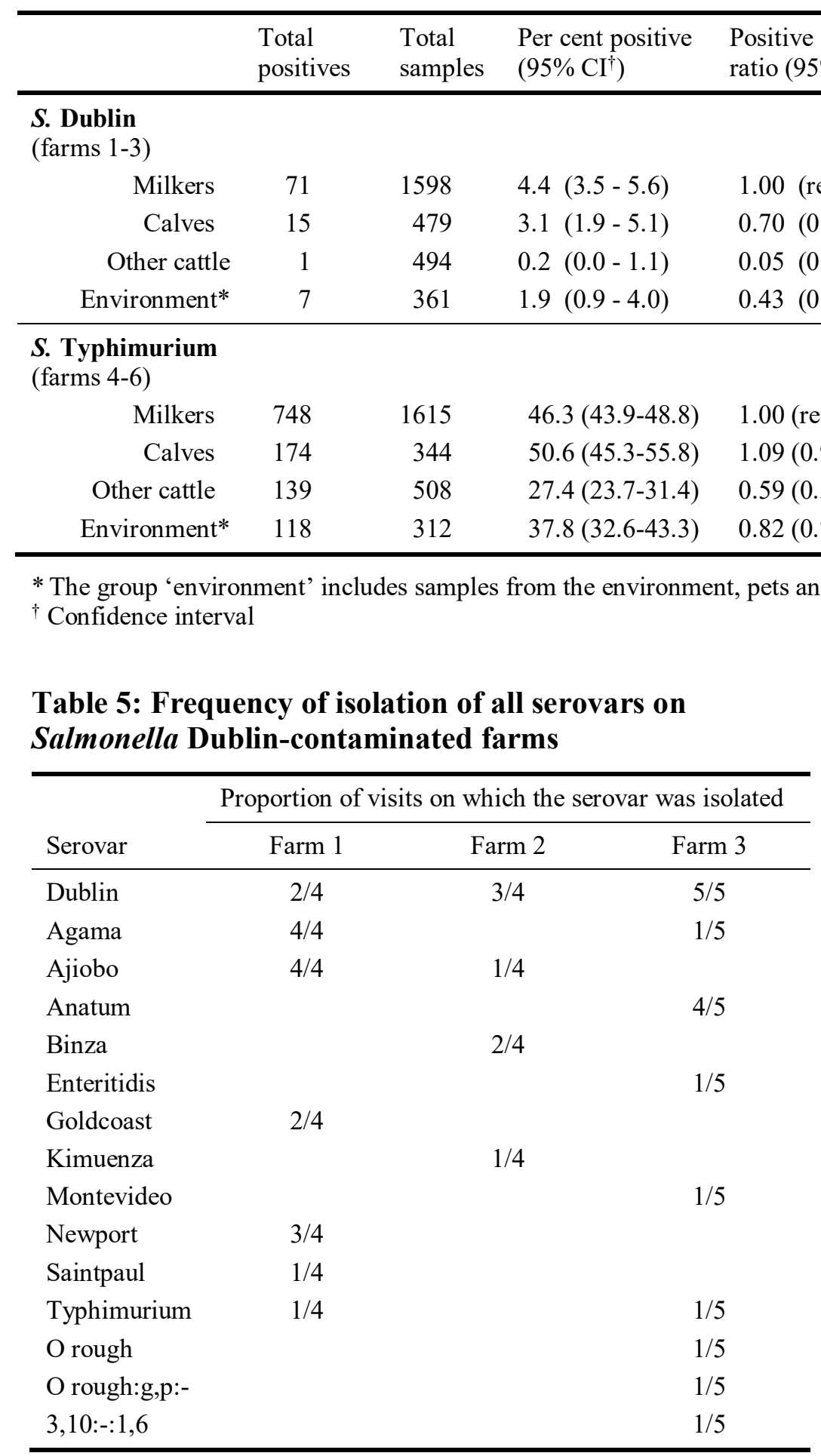



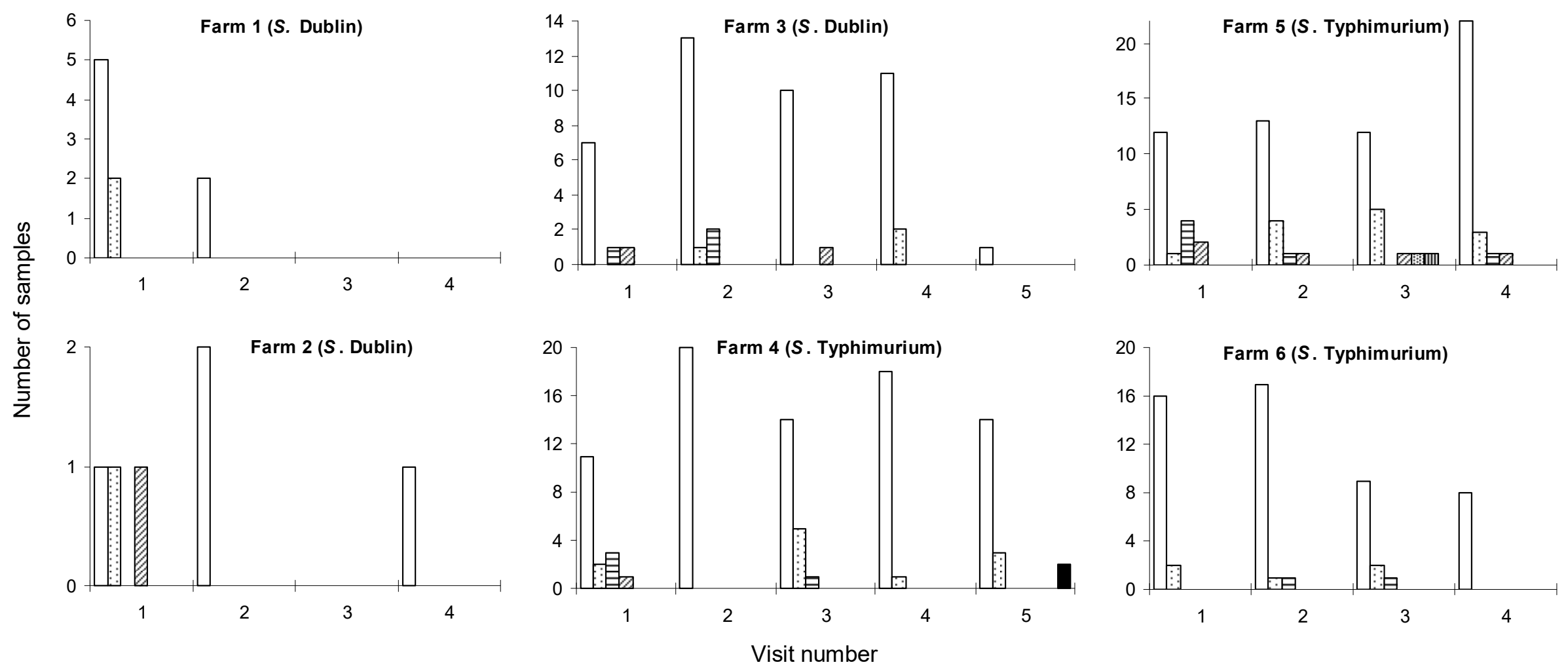

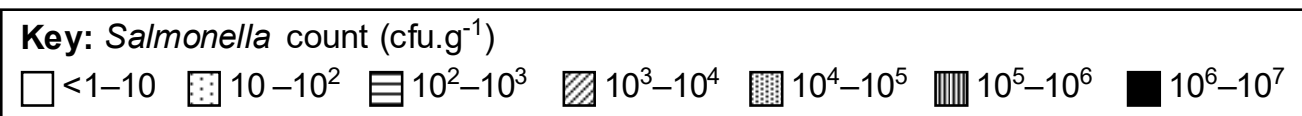

Figure: Salmonella counts in representative samples positive for Salmonella Dublin (farms 1 to 3) or Salmonella Typhimurium (farms 4 to 6). 